\title{
Study on Children's English Training Materials Market and Marketing Strategy Survey
}

\author{
Hefeng Wang ${ }^{1}$ \\ ${ }^{1}$ Luohe Medical College, Luohe, Henan, 462000 \\ ${ }^{a}$ email
}

Keywords: Children English; Market Structure; The Training Market

\begin{abstract}
Our children's English training materials market continues to develop, but because it is for children's English training institutions in this special customer groups, and there is more weak teachers, teaching in the form of rigid, unstable quality of teaching and other issues these training institutions, marketing Work many challenges. Press should be the basis of traditional marketing, the product from the past Books "sales service" to "education", and the book market and the education market resources integration, thereby forming a textbook as a platform to integrate resources a complete industrial chain of support points.
\end{abstract}

\section{Introduction}

In recent years, the book market overall downturn in the state, is one of the few children's books market growth, especially in children's English training materials market developed very rapidly. Thanks to this aspect of the level of economic development and improve English education has become an important part of the development strategy of the government; on the other hand due to the awakening of consciousness to educate parents, awareness of the importance of children's English education even more profound. It is estimated that Chinese children's English education market has reached hundreds of billion of annual giant, and an annual 20 percent to 30 percent rate of expansion, thus directly stimulating the demand for related materials markets. Analysis of children's English training materials market, good marketing, to root out potential publishers, marketing capabilities enhance the overall press is very important, while the integration of the publishing industry and the education industry, to further expand the publishing industry.

\section{The Market Structure}

Our children's English training materials publication dates back to the late 20th century introduced the Cambridge Young Learners English Test System. The test system consists of the University of Cambridge ESOL (UCLES) language experts after a long investigation and research, especially for non-English-speaking children 6 to 12 years of age to learn English and the design of a fusion of English learning and testing as one of the language training system. Its nature, adaptability, efficiency has been recognized by many countries and regions of the world. Then, under the joint efforts of Chinese and foreign English teaching experts accompanying "Cambridge Young Learners English" rapid publication. The kit is a listing once been widespread concern in the community, become hot in many English training institutions. After nearly two decades of development, "the Cambridge Young Learners English" in China has become a household renowned brand of education, is the most number of Chinese children learn English training school. Into the new century, China's children's English training market is showing explosive growth trend, training materials and publishing sales also will rise, surging. During this period, the market is more competitive, gradually showing the "Hundred Flowers", "Flowers" diversification pattern. Including the "Longman English", "Oxford English", "En English" English education at home and abroad, including many brands have joined the fight for market share among the tide. However, the domestic English training institutions started late, weak teachers, teaching in the form of rigid, unstable quality of teaching many reasons, drop out, drop out, changing schools is serious, while the formation of parents eager for their children to find the ideal training school; the other one side is 
one of many training institutions, "enough to eat" embarrassing situation, resulting in a huge contradiction training and education needs of the community is difficult to model and quality behind docking. Through research, we found that the domestic children's English training institutions in the development process mainly faced the following problems: (1) Brands factors: Most training institutions domestic children's English training market are in a non-brand status, while not in a certain area exclusive Acting well-known brands, the majority can not form its own unique charm. (2) Product factors: the domestic children's English training institutions, most of them operating in the homogeneity, no innovation, short product chain of children's English language training products, can not form a unique product advantages, can not attract potential customers on the product, while existing customer base and continue to drain. (3) Teacher factors: Due to the limited resources of local teachers, and no training related systems, resulting in a level of good teachers fall arrhythmia, training institutions and teachers during the disorderly competition for resources, resulting in rising costs of teachers, frequent staff turnover situation. (4) tube

Li factors: existing training institutions primarily responsible for most of the education industry background, not rich business management experience, training institutions resulting in internal management turmoil, unable to control the school's science operations, the final formation of internal friction, increased school operating costs. (5) competitive factors: the current training market lower the threshold, most training institutions run the same product, provide a simple service to monetize training only, in order to capture the market, vicious price competition, resulting in the regional training institutions lower profits, creating a vicious cycle. (6) Cost factors: training institutions in order to get more students have to take other measures to step up publicity efforts, so that the cost of the training institutions continue to increase. (7) supporting factors: the training institutions operates non-branded training, can not get any support, but can not use the brand for maximum profit growth.

\section{The Marketing Strategy}

Customer demand is marketing oriented. Problem children's English training institutions face today is the publisher engaged in marketing materials need to find ways to solve the problem. In the past, sales training materials are mostly rendered to the bookstore shelves books through traditional distribution channels. Teachers conducted by a handful of books in comparative screening, pick out their own teaching materials used. And then through their own efforts edge preparation, while the production of teaching aids, and gradually improve all aspects of teaching and learning activities. Multi-party publishing training materials for extensive marketing efforts, often playing ads on publishing professional media, to the agents Hair on souvenirs, more hope instructor autonomous choice. As the market changes and the increasing influx of competing products, the traditional marketing model has been unable to fully meet customer demand. Many customers in the choice of training materials at the same time, more is to understand that the publisher can provide a variety of educational support services, to help them in the near future courses, to hire the students as soon as possible to achieve profitability. This requires the publisher to do with the times, the old marketing concepts and tools to upgrade, rising from the past Books products, "marketing services" to "education services." Through market research and market combined with first-line work experience, summed up in the form of marketing and services cover the following six areas: first, to provide brand and product promotion services. Textbook publishers with the user through a variety of media channels, television, radio, Internet, periodicals, newspapers, etc., for children's English education as a whole to promote its brand and products packaging. Second, providing teacher training services. The user the ability to carry out comprehensive teacher training, curriculum quality teacher training, more training and teaching management training, management training principals, marketing manager training and the prospects of sales training and other services. Thirdly, marketing and recruitment services. With their own advantages publishers may invite experts and scholars to the field of education and training institutions offer seminars to parents and students to the concept of universal education, knowledge imparting education; dispatch full-time trainer personally teach open classes, enhance the visibility of the brand and product reputation . 
Fourth, the co-development of the market. Publisher with an excellent user cooperation for regional cooperation and development, shared benefits of space. Fifth, provide additional teaching and Admissions Services. To provide users with lesson plans, writing on the blackboard, paper materials games, teaching CD-ROM, cases and various publicity, recruitment and use of electronic templates. Sixth, provide incentives services. For partners to provide a variety of incentives including sports events, competitions outstanding student, teacher appraisal, appraisal and other schools. It is noteworthy that some English training materials market opened to the press, we are now moving steadily improving "educational services" concept. Outside the research community launched the "New Concept English" and "Cambridge International" two children's training materials include student teaching system are the product, several components such teacher training, online learning and education industry alliance, formed a complete set of learning systems and services .

FLTRP teacher training services useful features: In the product launch early generally have textbooks training services, after there will be training for the Senate courses that help teachers understand and use of materials; for teachers who want to improve their overall skills, FLTRP also relying on strong research and teaching capacity of Beijing Foreign Studies University, to provide professional in-depth training, including voice, child psychology, teaching methods, teaching practice and other courses. In improving "educational services" concept at the same time, publishers can also be further integration of resources among industries, the publishing industry, the education industry integration, the formation of cross-industry comprehensive development system. Provide education for the book publishing industry development platform, the book publishing industry to extend the influence of education. For the planned publication of children's English training materials for educational institutions, their products and expand the chain education services closely linked. Huge demand for education and training industry for the book ready for sale a stable and strong market. As early as 2003 had already entered the Chinese mainland market, "Kid Castle" children's English, is Taiwan, China since 1986, the creation of children's English training brand. In Taiwan, Kid Castle English kindergartens and schools of the four hundred, more than fifteen hundred kindergartens and more than 700 primary designated choice Kid Castle English textbooks. In mainland China, Kid Castle English has covered more than 20 provinces, autonomous regions and municipalities, covering more than fifty cities, the establishment of three hundred Yu Suoji Fort bilingual kindergarten and children's English training institutions, units have been developed using materials six thousand. The secret of a textbook holding nearly three decades vitality lies Kidcastle build a complete industrial chain chain of training, in addition to the book products, but also provides the service of teaching, teacher training, brand image, teaching management, authorization and a series of chain management services.

Children's English training materials for marketing promotion has gone far beyond the traditional book before product marketing model, toward the education industry and the development of large integration. Textbook is no longer a simple concept of a single book, Jane, but a rich content, various forms of educational programs. This educational project is based in textbooks as a platform to integrate resources for the support constructed a complete industrial chain.

\section{Acknowledgements}

This is the year 2015 in Henan Province Science and Technology Agency soft science research project. Item Number: 152400410553

\section{References}

[1] Liu Wei. Investigation and Analysis Cambridge Young Learners English project [J]. Modern Education Science, 2007 (2): 80-81.

[2] Wang Dong. Textbook publishing children's English training opportunities wide open: become more practical content publishing convoy training [N]. China Book Business Report, 2009-12-15. 
[3] Samo Wa, Potter intercultural communication [M]. Ae Huiquan, Wang Wei, Xu Peixi, et al., Beijing: China Renmin University Press, 2010.

[4] Lu Xiaohua. international media competition and selection of China - the ability to enhance international communication and the "Chinese television network" launch [J]. News and Writing, 2012 (02): 10-13.

[5] Sui Xin, Shao Tong. Cultural Conflict and Fusion Intercultural Communication Perspective [J]. Social Science Journal, 2013 (3): 51-55. 